\title{
Innovation Study of Ideological and Political Education in the Media Age
}

\author{
Yan Liu \\ School of Marxism \\ Northeast Dianli University \\ Jinlin, China
}

\begin{abstract}
This article elaborates the concept of media and its origin, through analysis of the application of the status quo "we media" in the ideological and political work, this paper describes countermeasures of the ideological and political education in the we media era.
\end{abstract}

Keywords - "We Media”; ideological and political education

\section{INTRODUCTION}

The media first appeared in the American scholar Dan Gillmor monograph "We Media". The American Press Institute Media Center Publicated study of "We Media" by Shayne Bowman and Chris Willis, and make a very long definition of the "We Media" : We Media is a way to begin to understand how ordinary citizens, empowered by digital technologies that connect knowledge throughout the globe, are contibuting to and participanting in their own truths, their own kind of news. In short, the media is a kind of carrier that citizens publish their own eyes saw and heard, such as blog, microblogging, weChat, forums / BBS and other network communities. In the media age, a variety of voices are from all sides, "mainstream media" voice became weaker, people no longer accept told correct or fault of the "unified voice", everyone judges things from the information obtained.

The media is different from information Broadcast led by the professional media organizations, It is information dissemination activities led by the general public, "We Media"has changed the long-standing pattern of information dissemination, the media is one kind of spread from the traditional "point to the surface"into "Peer to Peer".At the same time, the media also refers to one kind way of spread providing information on production, accumulation, sharing and dissemination of both privacy and openness contents of information dissemination for individual. Convenient, fast, simple, refined is the best interpretation the mass media, began to spread rapidly and go popular, We Media culture has profoundly changed the public's way of life, way of communication, social psychology and values.

Mobile phone applications in people's lives are no longer confined to receiving calls and receiving text messages, through which the operator provided convenient Internet services, mobile phones have become people carrying the pocket computer. According to the Internet statistics show, up to December 2015, China's mobile phone users reached
620 million, mobile Internet users ratio of $90.1 \%$.According to the "China Internet Development Statistics Report" data show that up to December 2015, the number of Internet users in China has reached 688 million, the number of mobile Internet access is as high as 620 million, The proportion of mobile phone users compared to the end of 2014 increased by 4.3 percentage points, the student population is still the largest proportion of Internet users in the group, about $29.9 \%$ [1]. In the era of rapid development of the information media, for ideological and political education in colleges and universities, how to accurately grasp the opportunity of "We Media", scientific and rational use of Wemedia to innovate ideological and political education work is the focus of ideological and political education in colleges and universities.

\section{The COMMUnist PARTY OF CHINA DEMAND TO STRENGTHEN THE CONTROL OF PUBLIC OPINION}

The report of the 18th National Congress of the Communist Party of China clearly demands that we should firmly grasp the leadership and initiative of the ideological work, insist on the correct orientation, enhance the guiding ability and strengthen the mainstream ideological and public opinion.College ideological and political education workers in the process of ideological and political education, we must closely follow the pace of the times, always concerned about the ideological changes and behavior of college students, an accurate understanding of college students' points of interest and points of interest, and constantly find innovative ways of ideological and political education. Mark Post in the "second media age" that the network of ideological and moral education has a higher cultural and technological content, should make students in the subtle influence [2].

\section{The Status Quo of We Media IN The IDEOLOGICAL AND POLITICAL WORK}

General Office of the CPC Central Committee and Office of the State Council jointly issued "further strengthen and improve the ideological and political work under the new situation"clearly pointed out: colleges and universities should focus on improving network applications, Applying "Net Language" to participate in Network Culture Construction and Management. With the development and application of we media in colleges and universities, we 
media in the ideological and political education work lies the following problems.

\section{A. We Media Platform Increased, but the Utilization Rate Is Low}

The first red website was established in 1998 in china, Tsinghua University students created learning network of Marxist theory in a class form by the Internet, and the site named "red site." the construction of the"red site" craze in the nation wide, the "Red Alliance website "unified the ideological and political education network of colleges and universities in the form of "Union", the number of colleges and universities to join the Union is increasing. With the "Chinese University Students Online" website established by the Ministry of Education, colleges and universities have independently created a series of forum websites with their own characteristics, such as "The Lily Forum" of Nanjing University, "Anqing Online" of Anhui University, "The system of the application of We-medium in the ideological and political education has gradually established and run well, such as establishing public universities of WeChat platform, as well as the establishment of official microblogging in microblogging platform. According to the characteristics of the university, the colleges and universities set up various courses to study the current situation, the dynamic display of current affairs policies, the real-time information push inside and outside school, the ideological and political education network counseling, the psychological counseling and the life service. The aim is to provide a new information platform for college students to study and develop. The ideological and political education in colleges and universities was impressive by carrying out the media.

"We Media" is widely used in ideological and political education work, However, the click rate of the red site, the proportion of teachers who participate in the interaction site still accounts for the majority, the proportion of students browsing the Web site is lower. The main reason is that the content ofthe network platform update slow and single obsolete, poor communication and immediate, not close the real life, ideological and political education platform blindly propaganda and preaching, which led the network platform not enable students to learn And live more convenient, students can not show themselves through the network platform better. At the same time, the operation of we media is the lack of innovation in colleges and universities, most of them are following the public to build the official wind blog, the public number and other online platforms, the League Committee, community organizations for ideological and political education established less professional platform, and content No new, which also led to the media platform a little substantive role.

\section{B. “We Media”Is Running Well in General, but the Regional Development Is not Balanced}

Sina microblogging micro-report published the "China Campus Microblogging Development Report (2015)",the statistics of the sample survey of the National University official microblogging establishment, as of June 2015, nearly
110 " 211 project "colleges and universities have established the official Bo, and run well, and based on these three indicators: dissemination power, coverage and activity of the official microblogging, the comprehensive ranking statistics of popular universities, Communist Youth League and the community, The cumulative impact of the top three is Fudan University, Wuhan University and Tsinghua University, the number of fans up to now have more than 500,000, we can see that microblogging this new media successfully attracted the attention of college students [3].At the same time, with the increase in mobile Internet users, colleges and universities at all levels and all kinds of groups also added a variety of WeChat public number, the idea of complex and diverse students focused on the campus concept through the use of open and free micro-communication environment .The micro-blog, WeChat and other public numbers created by colleges and universities are simple and novel in content, so that students can quickly read the school-related issues, such as the official WeChat public "ahugqt" established by the Communist Youth League of Anhui University, Certificated on August 24, 2015, its main function is to start from the ideological building, leading college students close to the community, to help students reshape lofty ideals. In the development of new media, "We Media" has gradually become a convenient platform for communication between schools and students. Its rich content and form has brought infinite vitality for the university campus.

"We Media"is more and more widely used in ideological and political education in colleges and universities, but the application of "We Media"in various colleges and universities is not balanced. First of all, the overall distribution from the country, the application and development of "We Media"is not balanced. According to the data show, the established university officials Bo concentrated in the southeast coastal areas, northwest region accounted for only about $6 \%$, while consciously established a special ideological and political education "We Media"platform in the"985 Project" and "211 Engineering "colleges and universities, the ordinary schools and colleges, vocational and technical colleges have a dedicated online ideological and political education platform for less than $20 \%$. Second, according to their own school conditions, the school's infrastructure construction and network coverage are also quite different, a narrow network of channels makes the needs of college studentsnot meet the Internet, these indirectly make colleges and universities not carry out Ideological and political education reasonably by "We Media", It is very important to construct the campus culture and construct the teaching service platform reasonably.

\section{Supervision of "We Media"Is Facing the Challenge}

In the new media era environment, "We Media"provides a platform forcarrying out the work of ideological and political education, while university network supervision work faces the challenges. "We Media"has two sides of the characteristics, the majority of colleges and universities do the deploymentwell about the "We Media" platform monitoring work in advance. Peking University WeChat 
public releases the authoritative and official credibility of the rumor informationon the spread of the network rumors, and constantly enhance the ability of university students in identifying rumors of the network, and stricts school normsin order to maintain the order of the campus network platform .Some colleges and universities have taken the wemedia supervision measures, but we-media potential loopholes and risks are far beyond expectations, colleges and universities are still unable to accurately predict and control the serious challenges from we-media. At present, it is extremely difficult to set up a teaching team with both network skills and ideological and political education. Due to the lack of professional skills and accomplishment of the existing supervisors, the university is also weak in the judgment of campus public opinion. Emergency plan is not flexible enough, which make the application of We Mediain the ideological and political education work more difficult.

\section{THE COUNTERMEASURES OF IDEOLOGICAL AND Political EdUCATION IN COLLEGES AND UNIVERSITIES IN WE MEDIA ERA}

\section{A. Improve Network Security Awareness}

In recent years, network fraud cases occur frequently in colleges and universities, criminals use the network to induce and cheat students. The college students are not aware of the network security precautions, while colleges and universities carry out the ideological and political education by $\mathrm{We}$ media, it is also very necessary for college students to do network security publicity and education. In order to improve College Students' Safety Consciousness and Selfprotection Consciousness, colleges and universities should enhance the network security awareness of college students, and at the same time, improve their own legal literacy. College students enhance their own legal literacy through a variety of ways. Including elective courses in the law, participating legal lectures organizated and extracurricular societies and other forms in school. Although most college students can not be proficient in the law, students need to understand the relevant laws, focus on "knowledge and behavior" of unity. Of course, some students understand the law, and know the relevant legal provisions but sometimes they do not act in accordance with the law. In this regard, we can clearly see that the current stage of college students in the moral and legal aspects is in the "knowledge" and "line" separation of the situation.

\section{B. Improving the Quality and Ability of Ideological and Political Educators}

In the media age, ideological and political education workers should not only have a high level of political theory, but also master the modern educational technology. in order to adapt to the level of modern education, Educators should closely follow the development of the times, combined with the actual situation, and master the media technology and the characteristics of the media, to cultivate and shape college students. Ideological and political education workers should have a high professional quality, and to improve the current ideological and political education status quo. Only with a higher professional quality and ability, Ideological and political education workers use we media in the ideological and political education; with a high professional quality and ability the ideological and political education workers can play full level in the ideological and political education, and with a higher theoretical literacy the education workers can enhance students' interest in ideological and political education and improve the quality of students through the organic combination in Theory and reality of technology.

\section{Optimizing the We-media Environment of Ideological and Political Education in Colleges and Universities}

The management of ideological and political education in colleges and universities not only needs a good environment in the social background, but also needs to create a good campus environment. The traditional ideological and political education mainly focuses on the ideological and political education classroom, the forum and other practical activities. at this stage, ideological and political education in colleges and universities should be innovate teaching techniques and methods, and always maintain innovation and advanced nature of the ideological and political education with the development of science and technology. we-media network environment has an open character, we media not only can provide an opportunity to narrow the distance between subject and object for ideological and political education workers, but also to help ideological and political education workers quickly and accurately grasp the students' words and deeds.

\section{CONCLUSION}

Colleges and universities should always grasp the right of campus culture, and create a positive campus culture. The soft environment of campus culture is an effective hidden resource of the ideological and political education in the university. The development of college students' personality can not be separated from the main campus culture environment. In the new media era, the diversified campus culture environment can be transfered to college students by the media directly and rapidly, Colleges and universities should actively explore the internal relationship between media and campus culture, encourage college students to participate in campus culture construction, open group discussion platform and information feedback channels, and promote the common development of campus and individual students. Ideological and political education workers should make the ideological and political education we media platform more characteristics of the times, identify the focus of college students, to stimulate students in interest and enthusiasm, encourage and guide students to participate in social practice in positive and optimistic attitude, And strive to create a vibrant campus environment[4].

\section{REFERENCES}

[1] Qiheng Hu. The 37th Statistical Report on Internet Development in China[EB/OL].(2016-01-22)[2016-1-

30].http://www.cnnic.net.cn/hlwfzyj/hlwxzbg/hlwtjbg/201601/t20160 122 53271.htm. 
[2] Mark Post, The Second Media Age [M]. Nanjing University Press, 2005.

[3] East China University of Political Science and Law News Research Center, Fudan University, International Public Relations Research Center, 2015.

[4] Yongliang Lv. Research on Humanistic Care in Ideological and Political Education of "Micro - times" [D]. Liaoning University of Technology,2014. 